\title{
ANNOTATIONS
}

\section{London the Centre of Post-Graduate Ophthalmology}

It scarcely admits of doubt that London is without a rival in its wealth of clinical material, not only in ophthalmology, but also in other branches of medicine and surgery. For many years our brethren of the dominions and our cousins of America have regarded Vienna or Berlin as the Mecca of ophthalmology, and to a large extent have ignored London's splendid resources. We are now not interested to inquire as to the cause or causes of this neglect. One thing, at least, is certain at this juncture, namely, that it should not be allowed to continue. By organization and co-operation much may be done to make London what it should be, the world centre of post-graduate ophthalmology. The work should be undertaken now, so that when peace is an actual fact, London would be ready to receive the host of visitors wishful to better their knowledge of eye work who may confidently be expected to visit these shores. If individual hospitals find difficulties in the way of providing lectures and demonstrations or of finding adequate material for those purposes, might not such obstacles be got over by the union for teaching purposes of the existing institutions? To that union might be added certain other hospitals, more particularly such as care for diseases of the nervous and genito-urinary systems, while special attention should be paid to the teaching of physiological optics, bacteriology, pathology, and radiography. On the staff of such a centralized institute, as is here outlined, there would be room for the pure scientist as well as his ophthalmological colleague. The hospital element would be strictly subordinated to the main function of such a place-the teaching of ophthalmology. Such an amalgamation of forces could scarcely fail to influence the teaching of ophthalmology in the metropolis of a far-flung empire.

\section{The Oxford Diploma in Ophthalmology}

After an interval of three years the examination for the Diploma in Ophthalmology at Oxford is to be resumed. The examination will begin on Monday, July 21, 1919, and is open to persons whose names are on the Medical Register of the United Kingdom, and to Bachelors of Medicine or Doctors of Medicine of Universities outside the United Kingdom, who have received permission from the Board of the Faculty of Medicine.

Candidates will be required to produce evidence satisfactory to the Board that they have duly attended a Course of Clinical 
Ophthalmology for twelve months in connection with Hospitals and Institutions approved by the Board, and that they either have already obtained Certificates at Oxford of Courses of study in Ophthalmology, Physiological Optics, and the Anatomy of the Eye, or have served for a period of not less than twelve months since August, 1914, in the Forces of His Majesty or his Allies or the United States of America.

The examiners appointed for this year are Dr. G. Mackay, of Edinburgh, and Lieut.-Colonel R. H. Elliot, of London.

Most of the teaching staff having been engaged on military work, it has been found impossible to hold the ordinary two months' course of instruction at the University this year, and we think the authorities are to be congratulated on throwing the examination open for this occasion to those who have been serving their countries in the war, as it will afford an opportunity to many men to take this qualification before returning to their homes or settling down to regular practice again.

In 1920 and subsequent years the ordinary regulations and requirements, as set out in the Statute and Regulations, come into force again.

Anyone requiring any further information is advised to apply to the Assistant Registrar, University Registry, Oxford, from whom all details can be obtained.

\section{Blindness from Ophthalmia Neonatorum}

The National Committee for the Prevention of Blindness (New York), has issued a new edition of its " Summary of State Laws and Rulings relating to the Prevention of Blindness from Babies' Sore Eyes" (publication No. 9 of the series). A perusal of its contents shows that there has been a great advance in legislation since the first edition of this pamphlet appeared in 1916. The material is briefly summarized below:

1. The reporting of babies' sore eyes to the local health officer or to



2. The reporting law is printed on the birth certificate in $\quad \ldots .4610 \quad$,

3. Local health officers are authorized and required to secure medical attention for uncared-for cases, or to warn parents of the dangers

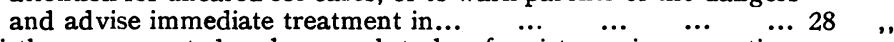

4. Births are reported early enough to be of assistance in prevention

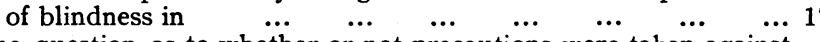

5. The question as to whether or not precautions were taken against ophthalmia neonatorum is included on the birth certificate in ... 19 ,

6. Free prophylactic outfits are distributed in $\begin{array}{llllllll}\ldots & \ldots & \ldots & \ldots & 22 & & & \ldots\end{array}$ $\begin{array}{llllll}\text { and strongly recommended in an additional } & \ldots & \ldots & \ldots & 4 & \end{array}$

7. The use of a prophylactic as a routine measure is compulsory in... 19 "

8. Popular educational leaflets, relating in whole or in part to prevention of infantile blindness, are distributed by State

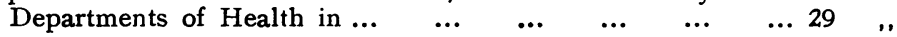

